\title{
UTILITY OF POLLUTION INDICES IN ASSESSMENT OF SOIL QUALITY AROUND MADAGA GOLD MINING SITE, NIGER STATE, NORTH-CENTRAL NIGERIA
}

\author{
${ }^{1 *}$ Amadi, A. N., ${ }^{1}$ Ebieme, E. E., ${ }^{1}$ Musa, A., ${ }^{2}$ Olashinde, P. I., ${ }^{1}$ Ameh, I. M. and ${ }^{3}$ Shuaibu, A. M. \\ ${ }^{1}$ Department of Geology, Federal University of Technology, Minna, Nigeria \\ ${ }^{2}$ Department of Geophysics, University of Ilorin, Nigeria \\ ${ }^{3}$ Department of Geological Sciences, Federal University Gusau, Zamfara State, Nigeria \\ *Corresponding Author's Email Address: geoama76@gmail.com or an.amadi@futminna.edu.ng \\ Phone No.: +234-80377-29977 \\ (Received: 10th July, 2017; Accepted: 22nd September, 2017)
}

ABSTRACT

\begin{abstract}
The quality of soil in the vicinity of Madaka mining sites were investigated in this study using Environmental Pollution Indices. Geological mapping of the study area indicated that the area was dominated by schist and granite. The static water level measurement revealed a westward groundwater flow direction which also coincides with the regional structural trend of the area. Laboratory analyses of soil and stream sediment were carried out in National Geosciences Research Laboratory Kaduna. The results of the soil analyses revealed high concentrations of mercury, cadmium, lead and arsenic. The results of the laboratory analysis were further elucidated using pollution indices such as geo-accumulation index, contamination factor, degree of contamination, elemental contamination index and metal pollution index. These environmental indices revealed that the soil is seriously polluted with mercury, cadmium and lead, moderately polluted with arsenic, lightly polluted with iron and copper and very lightly polluted with manganese, zinc, nickel and cobalt in the order of: $\mathrm{Hg}>\mathrm{Cd}>\mathrm{Pb}>\mathrm{As}>\mathrm{Fe}>\mathrm{Cu}>\mathrm{Mn}>\mathrm{Zn}>\mathrm{Ni}>\mathrm{Co}$. The mean concentrations of the first four metals $(\mathrm{Hg}, \mathrm{Cd}$, $\mathrm{Pb}$ and $\mathrm{As}$ ) exceeds their average crustal abundance, which is an indication of possible pollution. The concentrations map of the analyzed heavy metals indicated a westward decrease in concentration away from the mine sites. This was in agreement with the flow direction and the possible reduction in pollution intensity away from the mine sites could be attributed to the natural attenuation mechanism of soil in the course of groundwater migration as well as hydrogeological attributes of the area. The study recommends that the miners be grouped into association and trained on modern mining techniques that are environmental friendly. The polluted soils in the area should be remediated and proper sensitization on the dangers associated with artisanal mining should be carried out in the area. Periodic monitoring of the soil quality in the area is advocated.
\end{abstract}

Keywords: Utility, Environmental Pollution Indices, Impact, Artisanal Gold Mining, Madaga, Niger State, North-central Nigeria

\section{INTRODUCTION}

Soil quality determines the sustainability and productivity of agro-business of any nation. Soils are precious natural resources widely used as environmental indicators and their chemical analysis provide significant information on the assessment of anthropogenic activities of an area. They are important sinks for heavy metals and also play a significant role in the remobilization of contaminants under favourable conditions and interaction between soil and as well as water and sediments (Grosheva et al., 2000; Amadi et al., 2013). In recent years there have been increasing interests regarding heavy metal contaminations in soils, apparently due to their toxicity and perceived persistency within the aquatic systems and analysis of soil is a useful method of studying environmental pollution with heavy metals (Tijani et al., 2005).
They are essential requirements of human and industrial development and the most delicate part of the environment and so continuous monitoring of their quality status is essential to guarantee a safe environment. Therefore, a continuous monitoring of their quality is very essential to determine state of pollution in our environment. Stream sediment represents one of the ultimate sinks for heavy metals discharged into aquatic environment. Therefore, soil quality is a good indicator of pollution in water column, where it tends to concentrate the heavy metals and other organic pollutants (Saeed and Shaker, 2008; Amadi et al., 2014). Soil pollution, especially with heavy metals, has an important impact on environment and a direct potential threat on animal life (Wang et al., 2011, Amadi et al., 2012). Due to the ecological importance and the persistence of pollutants in the ecosystem, soils 
are more appropriate to be monitored in environmental evaluations and understand their potential toxic impacts (VonGunten et al., 1997; Kwon and Lee, 2001; Cesar et al., 2006). The research is aimed at determining the pollution level in soils around Madaka mining sites in Rafi Local Government Area of Niger State, Northcentral Nigeria.

\section{Statement of the Research}

The death of 28 children below the age five (17 female and 11 male) in Shikira and Madaka attributed to lead poisoning arising from artisanal gold mining in Madaka community was disturbing (The Guardian Newspaper $14^{\text {th }}$ May 2015). Unlike the Zamfara episode, livestock such as cows, goat and ram were affected. In order to protect the environment, comprehensive methods for identifying and assessing the severity of soil pollution was employed in order to ascertain the degree of pollution in soil, hence the need for the present study.

\section{Justification for the research}

The need to evaluate the quality status of soil and stream sediments around Madaka mining sites in Rafi Local Government Area of Niger State, North-Central Nigeria cannot be overemphasized owing to the $14^{\text {th }}$ May, 2015 episode. The investigation of the soil around the study area will provide baseline information for stakeholders on the causes and extent of pollution caused by artisanal mining in the area.

\section{Study area description}

The study area is part of Tegina Sheet 142SE and Alawa sheet 143SE. It lies between latitudes $\mathrm{N} 10^{\circ} 00^{\prime}$ to $\mathrm{N} 10^{\circ} 04^{\prime}$ of the Equator and longitudes $\mathrm{E}^{\circ} 6^{\circ} 26^{\prime}$ to $\mathrm{E} 06^{\circ} 34^{\prime}$ of the Greenwich Meridian (Fig. 1). The study area is drained by River Kaduna and its tributaries. The study area is accessible through Minna-Kagara road and other minor roads.

\section{Climate and vegetation}

The study area is characterized by two distinct seasons: the dry and rainy season. The mean annual rainfall in the area is $1200 \mathrm{~mm}$ while the minimum and maximum temperatures are $26^{\circ} \mathrm{C}$ and $34^{\circ} \mathrm{C}$ respectively. The vegetation of the study area is typical Guinea savannah which comprises tall grasses with series of tall trees within the vegetation. The trees become more populated along river channels (Federal Meteorological Agency, Minna, 2011, Ajibade, 1982).

\section{Geology of the Area}

The Madaka area is part of the Precambrian Basement Complex of Nigeria and the area is characterized by two distinct lithological units which comprises schist and the Older Granite suite. Russ (1957) categorized the schist in the area as Kushaka Schist Belt, which he described as multi-compositional (meta-siltstones, tremoliteschist, garnet-rich bands and carbonaceous schists). The abrupt changes in the schist (metasediment) conform to the finding of Russ, (1957) that the schist in the area lies unconformably with the underlying granitic rocks (Fig. 1). The schist in the area is commonly intruded by quartzites which are usually ironstained on weathered surfaces and along joints. The quartzites are fine grained and represent original siltstone or sandstone often of high ferrugious origin and this is also reported by Trustwell et al., (1963). The granitic rocks in the study area are predominantly granodiorite which covers most part of Madaka town. The previous work of Russ (1957) described the granodiorite in the area to be medium-porphyritic biotite-rich granodiorite. The granodiorite in the area has undergone intense structural deformation with different structural elements prominent on the rock. 


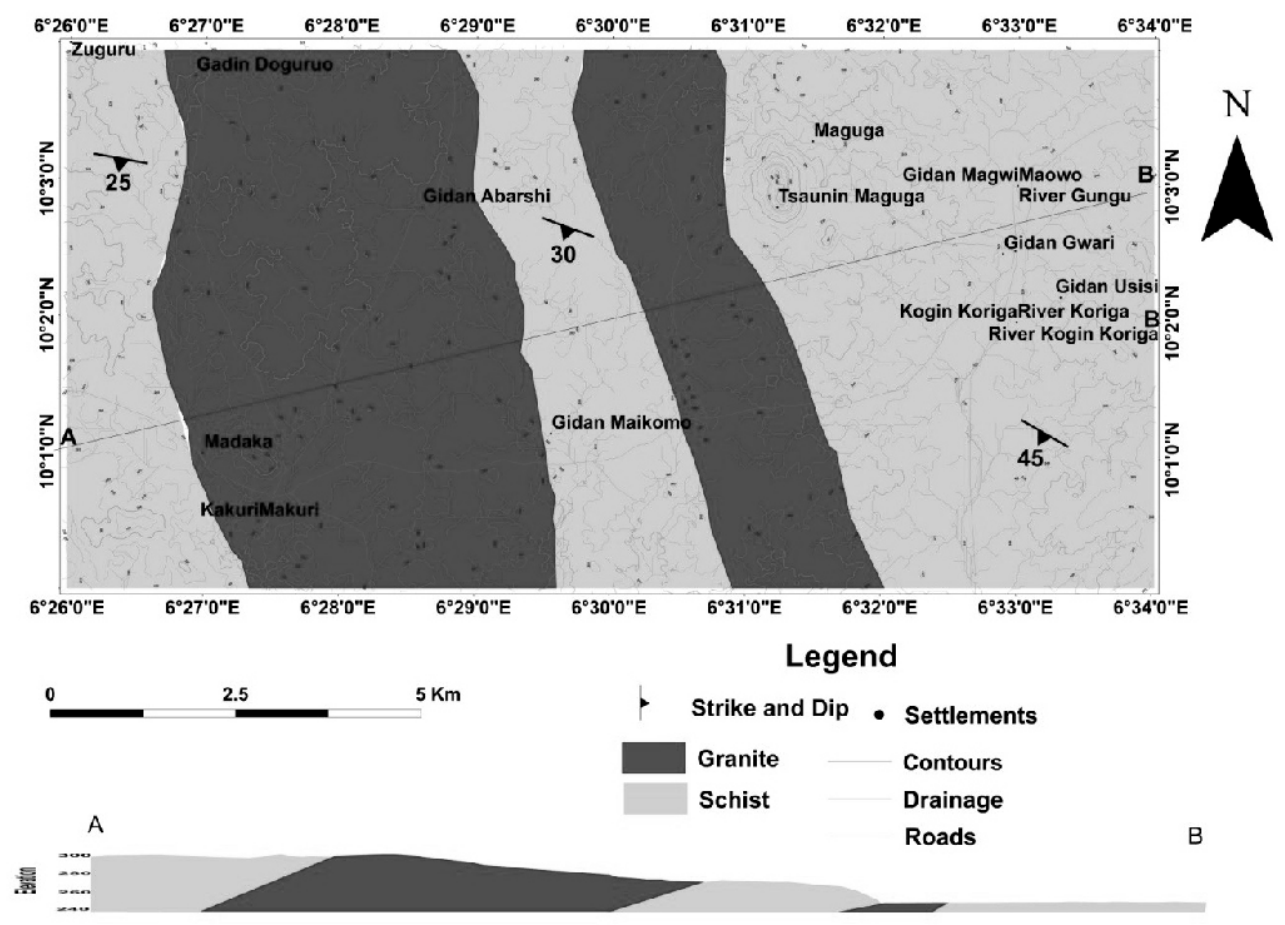

Fig. 1: Map of the Study Area

MATERIALS AND METHODS

Soil Samples, Preparation and Analysis

A total of thirty-five soil samples were collected in separate polythene bags for the present study. Thirty samples were collected within the vicinity of the mining sites while five samples were collected far away from the mining sites which serve as control samples. The soil samples were air-dried under shade and ground to pass through a $0.5 \mathrm{~mm}$ sieve for metal determinations and analyzed using the total digestion method. $0.5 \mathrm{~g}$ soil was weighed into a $100 \mathrm{~cm}^{3}$ beaker. $5 \mathrm{~cm}^{3}$ of concentrated $\mathrm{HNO}_{3}$ was added and this was boiled gently for $30 \mathrm{~min}$ on a hot plate. The beaker was cooled and $2 \mathrm{~cm}^{3} \mathrm{HClO}_{4}$ and $5 \mathrm{~cm}^{3}$ concentrated $\mathrm{HNO}_{3}$ were added. The mixture was heated to near dryness. The corners and walls of the beakers were washed with distilled water, and the solution was again heated until dense white fumes developed. The beaker was cooled and 10 $\mathrm{cm}^{3} \mathrm{HNO}_{3}$ was added to dissolve the salts in accordance with the USEPA method for soil analysis. The solution was transferred into a 50 $\mathrm{cm}^{3}$ standard flask and then diluted with distilled water. The extracts were analyzed by atomic absorption spectrophotometer (Perkin Elmer, Model No. 2380). The analyses were carried out at the National Geosciences Laboratory, Kaduna, Nigeria.

\section{Environmental Pollution Indices}

The results of the laboratory analyses were further interpreted using index of geo-accumulation, contamination factor, degree of contamination, metal pollution index, elemental pollution index and correlation analysis. The results of soil analysis were further compared with Wedepohl, (1995) as well as Taylor and Mclaennan, (1995) recommended elemental average crustal abundance/background values.

\section{RESULTS AND DISCUSSIONS}

The statistical summary of the results of laboratory analysis of the heavy metals in soils around Madaka mining sites are contained in Table 1, while Table 2 shows the average crustal abundance of the analyzed metals according to Wedepohl, (1995) as well as Taylor and Mclaennan, (1995). Ten metals (Mn, Cd, Hg, Pb, $\mathrm{Cu}, \mathrm{Zn}, \mathrm{Co}, \mathrm{Ni}, \mathrm{As}$ and $\mathrm{Fe}$ ) were used in the present study. The use of agro-chemical in intensive agriculture as well artisanal mining in the area are the potential pathways through which soils are enriched with heavy metal and it reduces the soil cohesiveness leading to an increase of erosion and leaching. The enrichment of soil by these metals is a function of soil $\mathrm{pH}$, grain size, organic matter, cation exchange capacity and hydraulic conductivity (Amadi, 2013). The $\mathrm{pH}$ of 
soils in the area ranged from 3.2 to 7.8 with a mean value of 4.7 , indicating that the soils in the area were acidic. The low $\mathrm{pH}$ of soils in the area increases the sorption rate of these metals. That is, the lower the $\mathrm{pH}$ value the more metal can be found in solution and thus more metals is mobilized into the surrounding soils.

The soil organic matter is important for the retention of metals by soil solids, thus decreasing mobility, however at lower $\mathrm{pH}$, metals tend to be more soluble and mobile in soils (Nachtergaele et al., 2002). Grain size plays an important role in the mobility of metals in soils. The grain size helps in diffusion of metal ions into and out of soil aggregates. The soils in the area were loose due to the agricultural and mining activities in the area thereby enhancing the permeability. The concentrations of manganese in the soil samples analyzed ranged from $57.21-504.42$ ppm with a mean value of $249.05 \mathrm{ppm}$. The mean concentration of manganese in the soils was lower than the standard of 527 ppm given by Wedepohl (1995) and 600 ppm given by Taylor and Mclenna (1995).

Table 1: Statistical Summary of Metal Concentrations in Soil from Madaka Area

\begin{tabular}{lllll}
\hline Parameters $(\mathrm{ppm})$ & Minimum & Maximum & Mean & Std. Deviation \\
\hline Manganese & 57.21 & 504.42 & 249.06 & 117.44 \\
Cadmium & 55.30 & 116.91 & 87.57 & 16.87 \\
Mercury & 28.49 & 70.25 & 50.17 & 12.12 \\
Lead & 0.92 & 808.16 & 194.41 & 265.87 \\
Copper & $\mathrm{ND}$ & 217.22 & 32.94 & 66.84 \\
Zinc & 18.55 & 119.81 & 38.54 & 28.35 \\
Cobalt & 0.00 & 7.76 & 0.99 & 1.88 \\
Nickel & 2.87 & 38.48 & 8.95 & 8.19 \\
Arsenic & ND & 3.05 & 0.35 & 0.81 \\
Iron & 5960.01 & 98005.36 & 27511.52 & 21128.16 \\
pH & 3.20 & 7.80 & 4.70 & 5.60 \\
\hline
\end{tabular}

ND $=$ Not detected

Table 2: Mean concentration of Metals in soils around Madaka Mining Sites compared their Average Crustal Abundance (Wedepohl,(1995); Taylor and Mclenna, (1995)

\begin{tabular}{llllll}
\hline Parameters & \multicolumn{3}{c}{ Mean conc. } & \multicolumn{4}{c}{ Guideline for maximum allowable limit in upper continental crust } \\
& $(\mathrm{ppm})$ & Wedepohl,(1995) & Status & Taylor and Mclenna (1995) & Status \\
\hline $\mathrm{Mn}$ & 249.05 & $527 \mathrm{ppm}$ & Low & $600 \mathrm{ppm}$ & Low \\
$\mathrm{Cd}$ & 87.57 & $0.102 \mathrm{ppm}$ & High & $0.098 \mathrm{ppm}$ & High \\
$\mathrm{Hg}$ & 50.16 & $0.056 \mathrm{ppm}$ & High & $0.040 \mathrm{ppm}$ & High \\
$\mathrm{Pb}$ & 194.41 & $17 \mathrm{ppm}$ & High & $20 \mathrm{ppm}$ & High \\
$\mathrm{Cu}$ & 32.94 & $14.3 \mathrm{ppm}$ & High & $25 \mathrm{ppm}$ & High \\
$\mathrm{Zn}$ & 38.54 & $52 \mathrm{ppm}$ & Low & $71 \mathrm{ppm}$ & Low \\
$\mathrm{Co}$ & 0.99 & $11.6 \mathrm{ppm}$ & Low & $10 \mathrm{ppm}$ & Low \\
$\mathrm{Ni}$ & 8.95 & $18.6 \mathrm{ppm}$ & Low & $20 \mathrm{ppm}$ & Low \\
$\mathrm{As}$ & 0.35 & $0.055 \mathrm{ppm}$ & High & $0.050 \mathrm{ppm}$ & High \\
$\mathrm{Fe}$ & 27511.52 & $30890 \mathrm{ppm}$ & Low & $7.07 \% \mathrm{wt}$ & Low \\
\hline
\end{tabular}




\section{Classification by Wedepohl, (1995) and Taylor and McLennan (1995)}

Heavy metals associated with gold mining are of particular interest due to their accumulation effects in soils as well as non-biodegradable nature, they tend to remain in soils for a very long time. The mean concentration of the ten elements used in the study was compared with maximum allowable limit in upper continental crust (Table 2). The classification by Wedepohl, (1995) as well as Taylor and McLennan (1995) indicate that the concentration of cadmium, lead, mercury and arsenic were high in soils from Madaka mining sites. However, copper was classified high based on Wedepohl, (1995) and Taylor and McLennan (1995) classification model (Table 2; Adams et al., 2008; Anglin-Brown et al., 1995; Ali and Fisher,
This showed that there was no contamination in any of the locations. Manganese is an essential element for plant and animal growth and development. Manganese can be adsorbed by soil, depending on the organic content and cation exchange capacity of the soil. The concentration map of manganese in soils around Madaka mining sites is shown in Figure 2. Cadmium concentration in the soil samples analyzed varied between 55.30 - $116.91 \mathrm{ppm}$ with an average concentration of $87.57 \mathrm{ppm}$ (Table 1). Cadmium is a relatively rare metal and is the $67^{\text {th }}$ most abundant elements in the earth crust with crustal abundance of 0.15 $\mathrm{ppm}$ in soils. The results of the analyses revealed that the samples of soil in the area were highly polluted with cadmium. 2005).

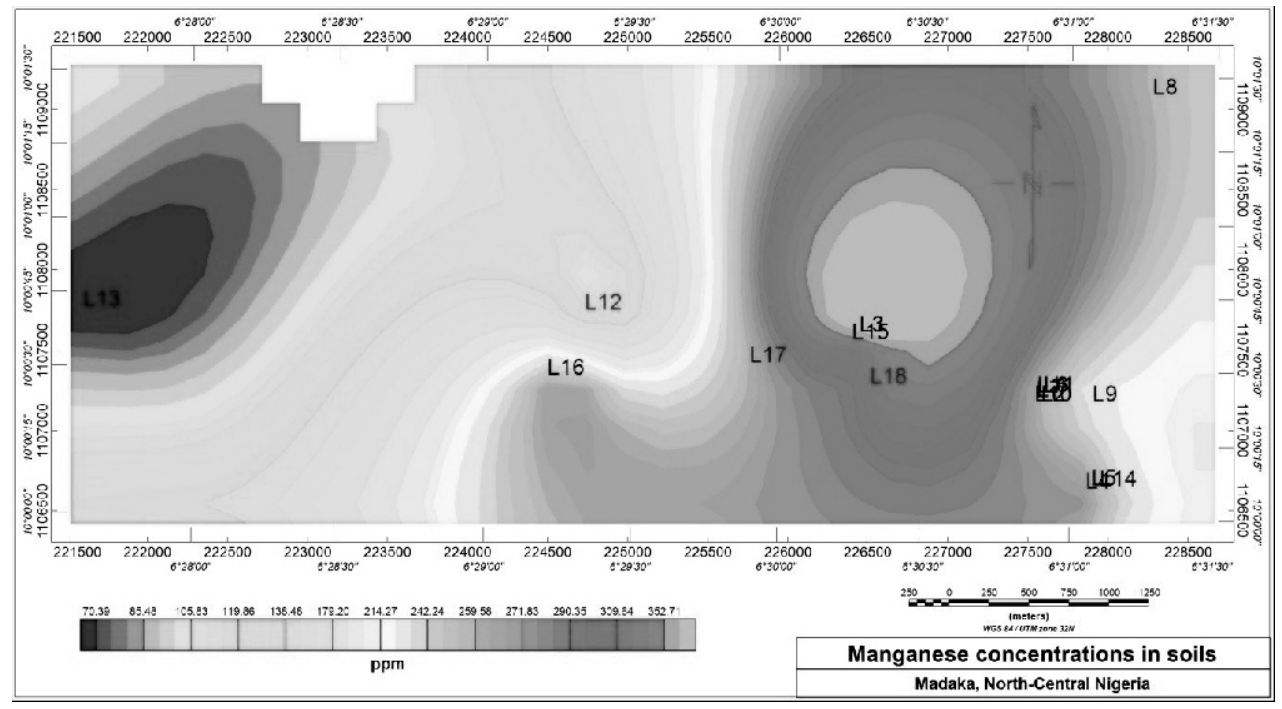

Fig. 2: Map of manganese concentration in soils from Madaka area

All the values are above the specifications of 0.102 ppm of Wedepohl (1995) and 0.098 ppm given by Taylor and Mclenna (1995). Cadmium is extremely toxic and the primary use of soil high in cadmium in form of manure for the cultivation of vegetables and other food crops could cause adverse health effect to consumers such as renal disease and cancer (Gorenc et al., 2004). The concentration map of cadmium in the study area (Figure 3) revealed that the concentration of cadmium decreases away from the mining sites, which is an indication that anthropogenic activities in the area is responsible for high cadmium concentration in soils in the area. Cadmium solubility increases under low $\mathrm{pH}$ and forms soluble complexes which greatly increase its mobility and very little adsorption of cadmium by soil colloids, hydrous oxides, and organic matter takes place. At higher $\mathrm{pH}$ values greater than 6 , cadmium is absorbed by the soil solid phase or is precipitated, and the solution concentrations of cadmium is greatly reduced (Che et al. 2003; Aktar et al., 2010;). The concentration of lead in the soil from the area ranged between $0.92-808.16 \mathrm{ppm}$ with a mean concentration of $194.41 \mathrm{ppm}$ (Table 1). The concentration of lead was found to be high in locations 1, 2, 3, 4, 5, 6, 7, 8 and 11. There values are above the recommended $17 \mathrm{ppm}$ by Wedepohl (1995) as well as 20 ppm by Taylor and Mclenna (1995). The high pollution of the soil in the area by lead can be linked to the gold mining in the area. 


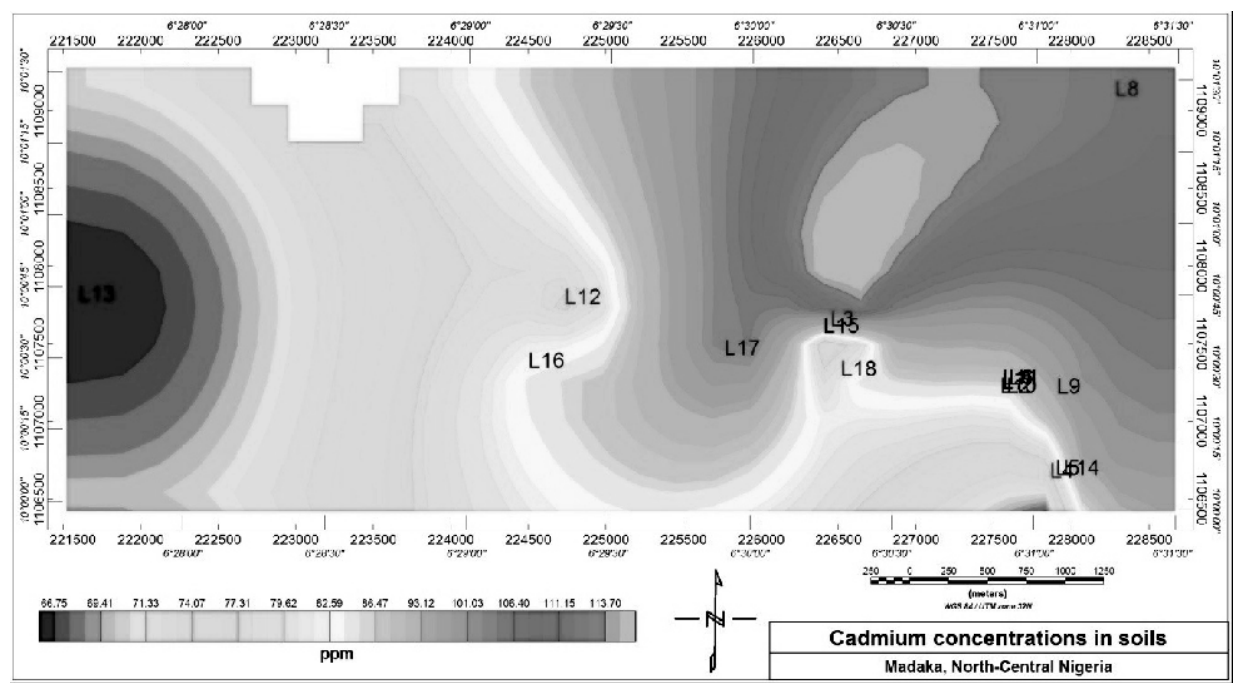

Fig. 3: Map of cadmium concentration in soils from Madaka area

Galena (PbS) is the ore hosting the gold in the area. It is most often discarded by the miners as gangue on the surrounding soils where they are weathered and subsequently leached into the subsurface. Lead toxicity causes cancer and anaemia by impairment of haemo-biosynthesis and acceleration of red blood cell destruction. The solubility of lead in soil solution is strongly influenced by the $\mathrm{pH}$. At $\mathrm{pH}$ values above $6, \mathrm{~Pb}$ is either adsorbed on clay surfaces or forms lead carbonate. At near neutral $\mathrm{pH}$ range, higher organic matter promotes the formation of organo-lead-complexes thereby increasing lead solubility (Ankley et al., 1992; liu et al., 2009). The concentration of lead in the study area is pictorially shown in figure 4 .

Concentrations of copper in the analysed soil samples varied from $0.00-217.22 \mathrm{ppm}$ with an average value of $32.94 \mathrm{ppm}$ (Table 1). Samples from locations 3, 4, 6, 7 and 8 are contaminated with copper. Locations 3, 4 and 7 have values exceeding Taylor and Mclenna (1995) acceptable value of $25 \mathrm{ppm}$ while values of locations $3,4,6,7$ and 8 also exceed Wedepohl (1995) acceptable value of $14.3 \mathrm{ppm}$. Copper is widely used in electrical wiring, roofing, various alloys, pigments, cooking utensils, piping and in the chemical industries (Aboud and Nandini, 2009).

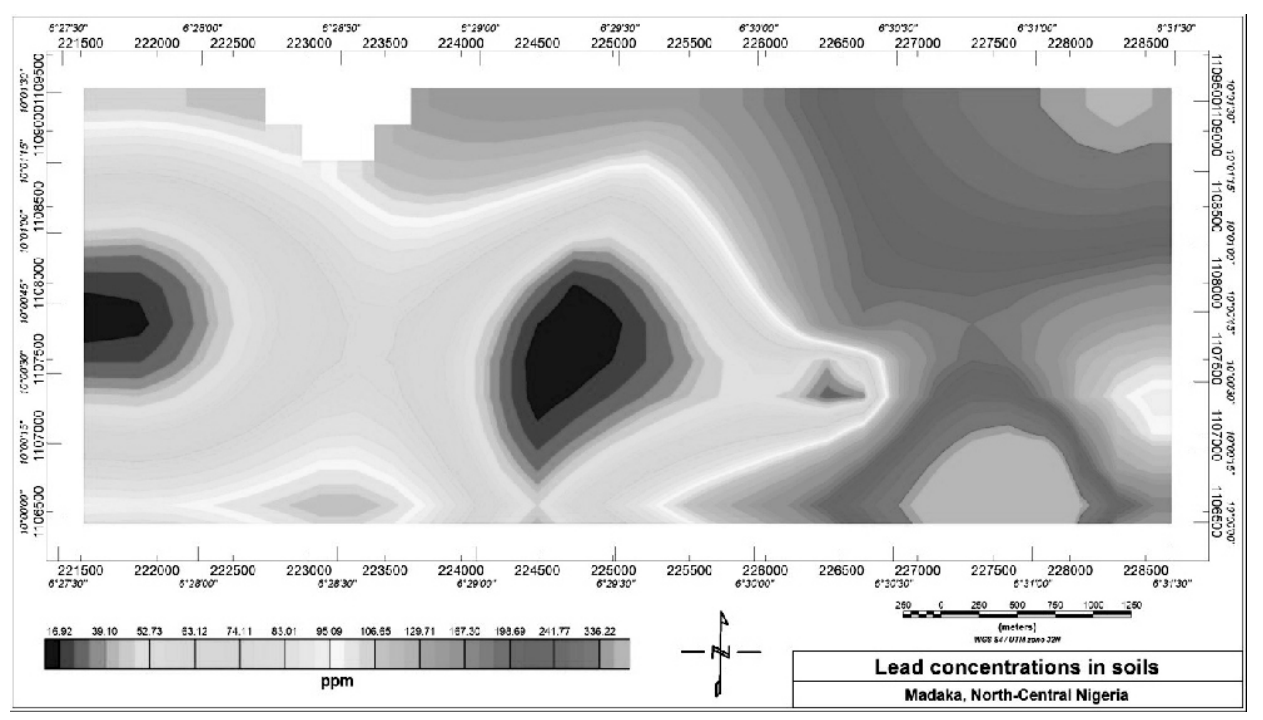

Fig. 4: Lead concentration map in soils from Madaka Area 
Copper compounds are used in fungicides, insecticides, electricity wires, wood preservation, electroplating, dye manufacture, engraving, lithography, petroleum refining and pyrotechnics. It is also added to fertilizers and animal feeds as a nutrient to support plant and animal growth (Mielke et al. 1991). Copper contamination in soils could result from weathering of copper-rich rocks discarded on the environment in the course of gold mining as well application of agro-chemicals on the farmland in the area. Exposure to high concentration of copper can lead to health problems such as pulmonary oedema, lung carcinoma and transitory fever (Pascual et al., 2004). In terms of rock types, gabbro and basalt have the highest concentration while granodiorite and granite have the lowest copper contents. This implies that soils derived from mafic rocks would have higher natural copper contents than those from felsic varieties (Pascual et al., 2004; Okunlola et al. 2016; Alloway, 1990; Nwankwoala et al.,
2017).

The concentrations of mercury in soil samples varied between 28.49 - $70.25 \mathrm{ppm}$ with a mean value of $50.17 \mathrm{ppm}$. The area is highly polluted with mercury as all the samples from all the locations were above the acceptable limits of both Wedepohl (1995) of $0.056 \mathrm{ppm}$ and the Taylor and Mclenna (1995) of $0.040 \mathrm{ppm}$ (Table 2). The use mercury by the miners in the processing of gold in the area may be responsible for the high content in soils and sediments. Mercury is a chemical element with atomic number 80 and a silvery-white metal which is liquid at ordinary temperature. It is a rare element with a crustal abundance of $0.08 \mathrm{ppm}$. It is found either as a native metal (rare) or in cinnabar $(\mathrm{HgS})$ and corderoite. The mobility of mercury increased with $\mathrm{pH}$ making mercury more soluble in water (Amadi et al., 2017). The distribution of mercury within the soils in the area is shown in Figure 5.

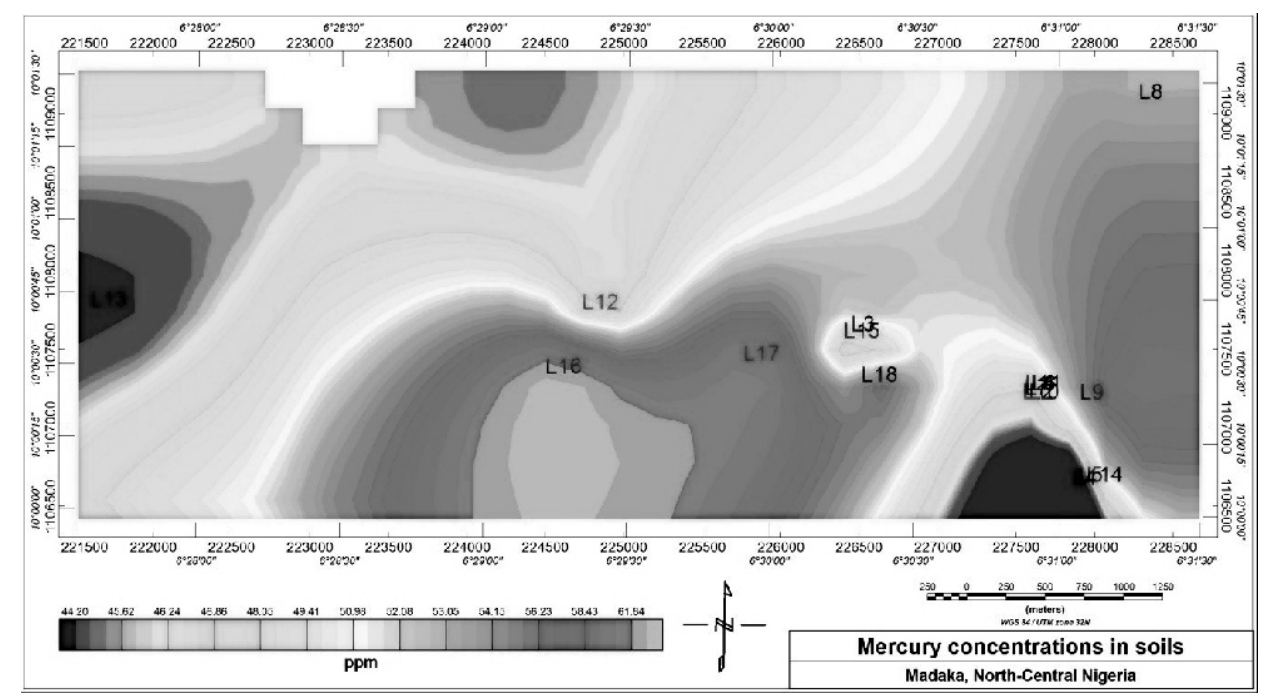

Fig. 5: Mercury concentration map in soils from Madaka area

The concentration of zinc in the study area ranged between $18.55-119.81 \mathrm{ppm}$ and a mean value of $38.54 \mathrm{ppm}$ (Table 1). Soil sample from locations 3 and 10 are found to exceed the acceptable limit of $52 \mathrm{ppm}$ of Wedepohl (1995), and only location 3 exceed $71 \mathrm{ppm}$ of Taylor and Mclennan (1995). The other concentrations of zinc in soils from the study area are within the stipulated guideline limits for an uncontaminated soil (Preda and Cox, 2002). Zinc is an essential element for plants, animals and human beings. Zinc concentration in soil is a function of the composition of parent rock, as well as anthropogenic activities such as mining. It is an essential growth element for plants and animals but can be toxic at elevated concentration. One main problem associated with high levels of zinc in the environment is its inhibitory effect to the uptake of copper, which is an essential element for plants. Excessive concentration of zinc in soil leads to phyto-toxicity. Acute zinc intoxication leads to nausea, vomiting, severe anaemia and renal failure (Aboud and Nandini, 2009). 
Nickel concentrations in the soil samples ranged between 2.87 - $38.28 \mathrm{ppm}$ with an average concentration of $9.95 \mathrm{ppm}$ (Table 1 ). These values are below the average crustal abundance of 80.00 ppm for an uncontaminated soil postulated by Dineley et al. (1976), which implies that the soil from the area is uncontaminated with respect to nickel. It is a major component in the production of stainless steels, non-ferrous alloys and super alloys. Other application of nickel includes electroplating, as catalysts, in nickel-cadmium batteries, coins, welding and electronic products (Pascual et al., 2004).

The concentration of arsenic ranged from $0.00-$ $3.05 \mathrm{ppm}$ with a mean concentration of $0.35 \mathrm{ppm}$. Soils samples from locations 1,3 and 5 have concentration exceeding the average crustal abundance. Arsenic is found to be above the acceptable limit of $0.055 \mathrm{ppm}$ and $0.050 \mathrm{ppm}$ of both Wedepohl (1995) and Taylor and Mclennan (1995) and this signifies pollution by arsenic in those locations. Studies have shown that soils overlying sulphide deposits and those in which pesticides have been applied can have chances of having high arsenic concentration. Arsenic is a pathfinder element to gold and it is usually discarded as gangue in the course of gold exploration by the artisanal miners. Over time, the host rock containing the arsenic gets weathered and the metal is released into the soil (Prasad and Kumari, 2008). Anthropogenic source of arsenic in the environment include the use of phosphatic fertilizers in farming as well as artisanal mining. Both $\mathrm{pH}$ and ionic exchange are important in determining the mobility of arsenic in soils. At high redox levels arsenic (IV) oxide predominates and arsenic mobility is low, and as the $\mathrm{pH}$ increases and redox level reduces arsenic (III) oxide becomes predominant thereby increasing its mobility because of its high solubility. The concentration map of arsenic within soils in the area is shown in figure 6.

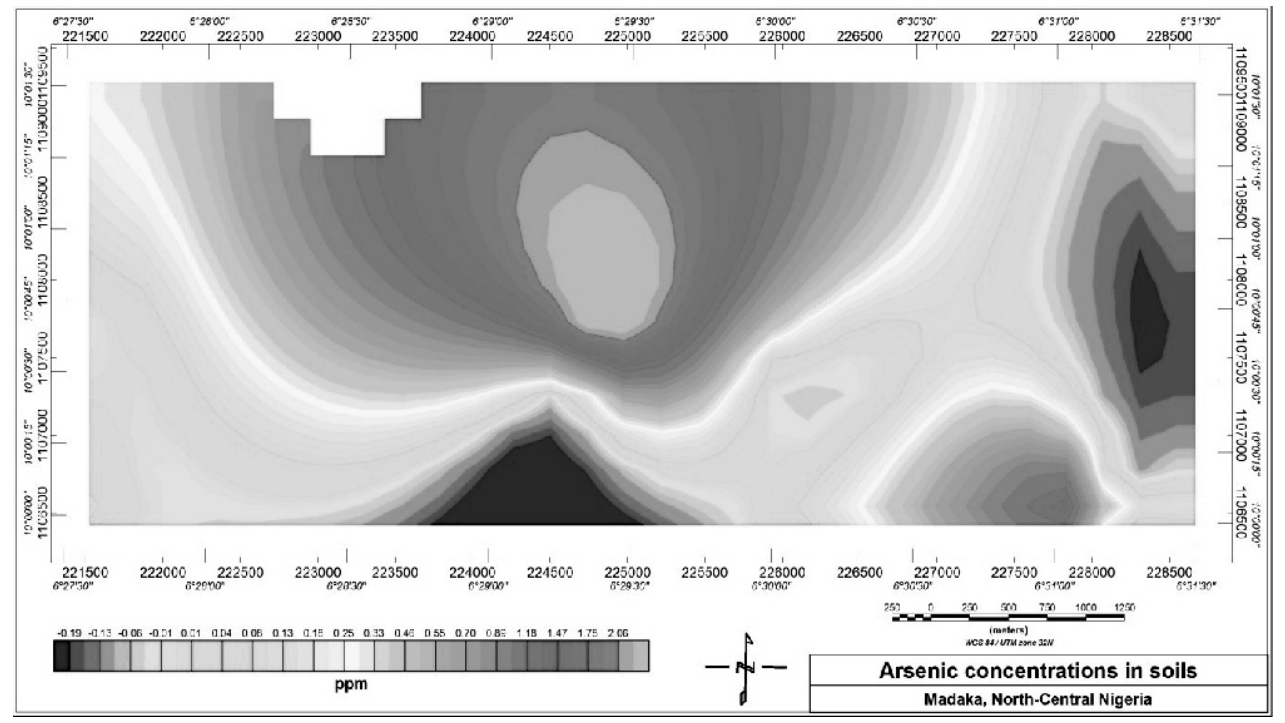

Fig. 6: Arsenic Concentration map in soils from Madaka area

The concentration of cobalt ranged from 0.00 $7.76 \mathrm{ppm}$ with a mean value of $0.99 \mathrm{ppm}$. There is no pollution by cobalt from all the sampled locations. Concentration of cobalt in all the locations are below the $11.6 \mathrm{ppm}$ of Wedepohl (1995) and $10 \mathrm{ppm}$ of Taylor and Mclennan (1995) Cobalt is carcinogenic and the health effects of cobalt include bronchitis, dermatitis and inflammation of the tissue (Aboud and Nandini, 2009). The concentration of iron in the soils ranged between 5,960.01 - 98,005.36 ppm with an average value of $27,511.52 \mathrm{ppm}$ (Table 1 ). The concentration of iron in soils is dependent upon the source rocks from which the soil was derived, transport mechanisms, and overall geochemical history. This is particularly true in soil and groundwater systems that have been environmentally impacted by mining. Iron occurs in one of two oxidation states: reduced soluble divalent ferrous iron $\left(\mathrm{Fe}^{+2}\right)$ or oxidized insoluble trivalent ferric iron $\left(\mathrm{Fe}^{+3}\right)$. It has been observed 
that the high iron value in soils from the area may be due to the interaction with iron contained in the lateritic soil.

\section{Environmental Pollution Indices}

In order to quantitatively ascertain the level and extent of heavy metal contamination in the soil around the vicinity of the mining sites, environmental pollution indices was applied which include: geo-accumulation index, contamination factor, degree of contamination, metal pollution index and elemental contamination index. The relationship among the metals was confirmed using Pearson's correlation analysis.

\section{Geo-accumulation index (Igeo)}

The results of the calculated Igeo for soils revealed that the soil from the area were highly polluted with cadmium, mercury and lead, lightly polluted with arsenic, very lightly polluted with iron and unpolluted with copper, manganese, zinc, cobalt and nickel (Tables 3). The enrichment of the soil by cadmium, mercury, lead and arsenic can be attributed to the artisanal mining going on in the area. They miners use mercury to concentrate gold in the course of processing, while lead, cadmium and arsenic occur as pathfinder elements to gold and are often discarded into the surrounding soil as gangue. Galena (PbS) is the ore hosting the gold in the area and associated with the galena are arsenic and cadmium. This may explain why the concentrations of some metals are high in soil in the order of: $\mathrm{Hg}>\mathrm{Cd}>\mathrm{Pb}>\mathrm{As}>\mathrm{Fe}>\mathrm{Cu}$ $>\mathrm{Zn} \mathrm{Ni}>\mathrm{Mn}>$ Co. Geological phenomenon such as weathering and dissolution releases these metals from their host rock into the nearby soil.

Table 3: Computed Geo-accumulation Index (Igeo) values for soil from Madaka mining sites

\begin{tabular}{llll}
\hline S/No & Parameters & Igeo & Pollution Intensity \\
\hline 1 & $\mathrm{Mn}$ & -0.59 & Unpolluted \\
2 & $\mathrm{Cd}$ & 6.35 & Very highly Polluted \\
3 & $\mathrm{Hg}$ & 6.72 & Very highly Polluted \\
4 & $\mathrm{~Pb}$ & 5.16 & Very highly Polluted \\
5 & $\mathrm{Cu}$ & 0.38 & Unpolluted \\
6 & $\mathrm{Zn}$ & -0.16 & Unpolluted \\
7 & $\mathrm{Co}$ & -2.36 & Unpolluted \\
8 & $\mathrm{Ni}$ & -0.52 & Unpolluted \\
9 & $\mathrm{As}$ & 2.44 & Lightly polluted \\
10 & $\mathrm{Fe}$ & 1.85 & Very lightly polluted \\
\hline
\end{tabular}

$<1$ = Unpolluted; Igeo $>1-\leq 2$ =Very Lightly Polluted;

$2<$ Igeo $\leq 3=$ Lightly Polluted; $3<$ Igeo $\leq 4=$ Moderately Polluted;

$4<$ Igeo $\leq 5=$ Highly Polluted; Igeo $>5=$ Very highly Polluted.

\section{Contamination Factor (CF)}

The result of the computed contamination factor for soil is shown in Table 4. The results revealed that the soil in the vicinity of Madaka mining site are highly contaminated with cadmium, mercury and lead, considerably contaminated with arsenic and iron, while the intensity of contamination by copper, manganese, zinc, cobalt and nickel were low. The contamination intensity of the analyzed heavy metals in soils decreased in the following order: $\mathrm{Hg}>\mathrm{Cd}>\mathrm{Pb}>\mathrm{As}>\mathrm{Fe}>\mathrm{Cu}>\mathrm{Zn}>\mathrm{Ni}$ $>\mathrm{Mn}>\mathrm{Co}$. The enrichment of these metals in the soil may be attributed to the anthropogenic activities going on in the area as well geogenic processes such as bedrock dissolution and chemical weathering (Amadi and Nwankwoala, 2013; Amadi, 2011). Majority of the observed elements are contained in the minerals that make up the host rock in the area and are exposed and subsequently released into the soil through human activities such as mining and farming. The similarity in the computed pollution intensity of both Igeo and CF is confirmation of the utility of environmental pollution indices in pollution studies. 
Table 4: Calculated Contamination Factor (CF) values for soil from Madaka mining sites

\begin{tabular}{llll}
\hline S/N & Parameters & CF & Contamination Factor \\
\hline 1 & $\mathrm{Mn}$ & 0.47 & Low Contamination \\
2 & $\mathrm{Cd}$ & 85.85 & Very High Contamination \\
3 & $\mathrm{Hg}$ & 89.51 & Very High Contamination \\
4 & $\mathrm{~Pb}$ & 11.43 & Very High Contamination \\
5 & $\mathrm{Cu}$ & 2.30 & Moderate Contamination \\
6 & $\mathrm{Zn}$ & 0.74 & Low Contamination \\
7 & $\mathrm{Co}$ & 0.08 & Low Contamination \\
8 & $\mathrm{Ni}$ & 0.48 & Low Contamination \\
9 & $\mathrm{As}$ & 4.36 & Considerable Contamination \\
10 & $\mathrm{Fe}$ & 1.45 & Moderate Contamination \\
\hline
\end{tabular}

$\mathrm{CF}<1=$ Low $\mathrm{CF} ; 1 \leq \mathrm{CF}<3=$ Moderate $\mathrm{CF} 3 \leq \mathrm{CF}<6=$ Considerable Contamination Factor; $\mathrm{CF} \geq 6$ $=$ Very High Contamination Factor

\section{Degree of Contamination $\left(\mathrm{C}_{\mathrm{d}}\right)$}

Four classes were used to describe the degree of contamination (Table 5). The summation (addition) of the contamination factors from Tables 3 for soil gave the corresponding $\mathbf{C d}$ value of 196.67, which falls in the class of very high degree of contamination (Table 5). The computed degree of contamination for the selected metals confirms that soils around Madaka mining sites are seriously contaminated with cadmium, lead and mercury and moderately contaminated with arsenic and the observed contamination may be coming from the various human activities domiciled in the area most especially the farming and mining.

Table 5: Degree of Contamination of soil from Madaka mining sites

\begin{tabular}{lll}
\hline $\mathrm{S} / \mathrm{N}$ & $\mathrm{Cd}$ Range & Degree of Contamination \\
\hline 1 & $\mathrm{Cd}<6$ & Low degree of contamination \\
2 & $6=\mathrm{Cd}<12$ & Moderate degree of contamination \\
3 & $12=\mathrm{Cd}<24$ & Considerable degree of contamination \\
4 & $\mathrm{Cd} \geq 24$ & Very high degree of contamination \\
\hline
\end{tabular}

\section{Metal Pollution Index (MPI)}

The results of the computed metal pollution index on the soil analyzed are illustrated in Table 6. It can be observed from these tables that the degree of metallic contamination in the soil ranges from strongly polluted (mercury, lead and cadmium), slightly polluted (arsenic, copper and iron) to unpolluted (manganese, zinc, cobalt and nickel). The decreasing order of the contaminant is: $\mathrm{Hg}$ $>\mathrm{Pb}>\mathrm{Cd}>\mathrm{As}>\mathrm{Cu}>\mathrm{Fe}>\mathrm{Mn}>\mathrm{Zn}>\mathrm{Co}>\mathrm{Ni}$. The leachate from the various human activities in the area is potential pathway through which the soil gets polluted. 
Table 6: Calculated Heavy Metal Pollution Index for Soils from Madaka mining sites

\begin{tabular}{lll}
\hline Parameters $(\mathrm{ppm})$ & HMPI Value & Rating \\
\hline $\mathrm{Mn}$ & 0.97 & Unpolluted \\
$\mathrm{Cd}$ & 22.50 & Strongly Polluted \\
$\mathrm{Hg}$ & 35.60 & Strongly Polluted \\
$\mathrm{Pb}$ & 26.80 & Strongly Polluted \\
$\mathrm{Cu}$ & 1.20 & Slightly Polluted \\
$\mathrm{Zn}$ & 0.95 & Unpolluted \\
$\mathrm{Co}$ & 0.56 & Unpolluted \\
$\mathrm{Ni}$ & 0.89 & Unpolluted \\
$\mathrm{As}$ & 1.50 & Slightly Polluted \\
$\mathrm{Fe}$ & 1.05 & Slightly Polluted \\
\hline
\end{tabular}

$<1=$ Unpolluted; $1-4.99=$ Slightly polluted $;-19.99=$ Moderately polluted;

$20-40=$ Strongly polluted; $>40=$ Very strongly polluted

\section{Elemental Pollution Index (EPI)}

The results of the computed elemental pollution index (EPI) for soil are contained in Table 7. Interestingly, in addition to index of geoaccumulation, contamination factor, degree of contamination and metal pollution index, the computed elemental pollution index values were similar, which is a clear indication that the soil in the vicinity of the mining sites within Madaka area are polluted mercury, cadmium lead and arsenic. The consistency in the pollution status of these four metals (mercury, cadmium lead and arsenic) across the five environmental indices used in this study justifies the efficiency of these pollution indices in environmental studies.

Table 7: Calculated Elemental Pollution Index for Soils from Madaka mining sites

\begin{tabular}{lll}
\hline Parameters $(\mathrm{ppm})$ & ECI Value & Rating \\
\hline $\mathrm{Mn}$ & -0.52 & Very Low Contamination \\
$\mathrm{Cd}$ & 75.30 & Very High Contamination \\
$\mathrm{Hg}$ & 84.24 & Very High Contamination \\
$\mathrm{Pb}$ & 60.43 & Very High Contamination \\
$\mathrm{Cu}$ & 1.27 & Very Low Contamination \\
$\mathrm{Zn}$ & -0.25 & Very Low Contamination \\
$\mathrm{Co}$ & -0.91 & Very Low Contamination \\
$\mathrm{Ni}$ & -0.52 & Very Low Contamination \\
$\mathrm{As}$ & 5.36 & Moderate Contamination \\
$\mathrm{Fe}$ & 3.05 & Very Low Contamination \\
\hline
\end{tabular}

$<5=$ very low contamination; $5-9.99=$ low contamination;

$10-24.99=$ medium contamination; $25-49.99=$ high contamination;

$50-100=$ very high contamination; $>100=$ extremely high contamination

\section{Correlation Analysis}

A strong positive correlation (Table 8) for the metals exists for all the metals except copper and arsenic. The two classes displayed in correlation coefficient suggest two potentials sources for the metals in soils in the area which can be linked to mining and agro-chemicals used in farming as well as weathering and bedrock dissolution and infiltration processes. 
Table 8: Pearson correlation coefficient matrix for heavy metals in soils from Madaka area

\begin{tabular}{lllllllllll}
\hline & $\mathrm{Fe}$ & $\mathrm{Cu}$ & $\mathrm{As}$ & $\mathrm{Ni}$ & $\mathrm{Co}$ & $\mathrm{Cd}$ & $\mathrm{Hg}$ & $\mathrm{Pb}$ & $\mathrm{Mn}$ & $\mathrm{Zn}$ \\
\hline $\mathrm{Fe}$ & 1.000 & & & & & & & & & \\
$\mathrm{Cu}$ & .155 & 1.000 & & & & & & & & \\
$\mathrm{As}$ & -.042 & -.114 & 1.000 & & & & & & & \\
$\mathrm{Ni}$ & $.797^{*}$ & .134 & -.135 & 1.000 & & & & & & \\
$\mathrm{Co}$ & $.999^{* *}$ & .161 & -.007 & $.792^{* *}$ & 1.000 & & & & & \\
$\mathrm{Cd}$ & $.997^{* *}$ & .156 & .034 & $.785^{* *}$ & .999 & 1.000 & & & & \\
$\mathrm{Hg}$ & $.731^{* *}$ & .123 & -.107 & $.613^{*}$ & .720 & .711 & 1.000 & & & \\
$\mathrm{~Pb}$ & $.997^{* *}$ & .174 & -.103 & $.801^{* *}$ & $.995^{* *}$ & $.990^{* *}$ & .734 & 1.000 & & \\
$\mathrm{Mn}$ & $.937^{* *}$ & .089 & -.127 & $.723^{* *}$ & $.930^{* *}$ & $.923^{* *}$ & $.680^{*}$ & $.940^{* *}$ & 1.000 & \\
$\mathrm{Zn}$ & $.563^{*}$ & .184 & -.050 & $.659^{*}$ & $.558^{*}$ & $.547^{*}$ & $.605^{*}$ & $.578^{*}$ & $.633^{*}$ & 1.000 \\
\hline
\end{tabular}

** Correlation is significant at the 0.01 level (1-tailed)

*. Correlation is significant at the 0.05 level (1-tailed)

\section{CONCLUSION}

This study has clearly established that artisanal mining and use of agro-chemicals in farming constitute a major source of soil pollution in the study area. It should be noted that the concentration of the metals decreased away from the mining sites and farm lands. The concentration maps of the analyzed metal in soils decreases away from the eastern portion (mining sites and farm land) to the western part (community). Natural attenuation mechanism such as ionic exchange, adsorption, absorption and dilution help in reducing the concentration of contaminant in the course of migration away from the mining sites. Environmental quality indices are powerful tools used in quantifying the pollution status of an area. The environmental pollution indices such geo-accumulation index, contamination factor, degree of contamination, elemental contamination index and metal pollution index revealed that the soil in the area are highly polluted with mercury, cadmium and lead, moderately polluted with arsenic, lightly polluted with iron and copper and unpolluted with manganese, zinc, cobalt and nickel in the order of: $\mathrm{Hg}>\mathrm{Cd}>\mathrm{Pb}>\mathrm{As}>\mathrm{Fe}>\mathrm{Cu}>\mathrm{Mn}>\mathrm{Zn}>\mathrm{Co}>$ Ni. Among significant variables that control the distribution and enrichment of heavy metals in soils are $\mathrm{pH}$ of soil, grain size of the soil, amount of organic matter in the soil and the cation exchange capacity of the soil (Lin et al., 2002). The soil $\mathrm{pH}$ is slightly low, signifying acidic soil while sandy-loamy soil characterize the top soil at the mine sites and farm-lands and these condition enhances the precipitation and bio-accumulation of heavy metals in soil. It is recommended that soils within the mining sites be remediated and Proper sensitization should be carried out in the area of the dangers of artisanal mining. Also the miners should be grouped into associations and equipped with modern mining tools.

\section{REFERENCE}

Aboud, S. J. and Nandini, N., (2009). Heavy metal analysis and sediment quality values in urban lakes. American Journal of Environmental Science, 5(6), 678-687.

Adams, R. H., Guzmán-Osorio, F. J. \& Zavala, C. J. (2008). Water repellency in oil contaminated sandy and clayey soils. International Journal of Environmental Science and Technology, 5(4), 445-454.

Ajibade, A. C. (1982). The origin of the Older Granites of Nigeria: some evidence from the Zungeru region. Nigerian Journal of Mining and Geology, 19, 223-230.

Ajibade, A. C. \& Wright, J. B.(1988).Structural Relationship in the Schist Belts of North Western Nigeria.In P.O Oluyide et al., (Eds).Precambrian geology of Nigeria.A publication of Geological Survey, 103109.

Aktar, M. W., Paramasivam. M., Ganguly, M., Purkait, S., \& Sengupta, D., (2010). Assessment and occurrence of various heavy metals in surface water of Ganga river around Kolkata: a study for toxicity and ecological impact. Environmental Monitoring and Assessment,160(2), 207-213. doi.10.1007/s10661-008-0688-5.

Ali, M. H. H. \& Fishar, M. R. A. (2005). Accumulation of trace metals in some 
benthic invertebrate and fish species relevant to their concentration in water and sediment of lake Qarun, Egypt. Egyptian J. of Aquatic Res. 31(1), 289301.

Alloway, B. J., (1990). Heavy metals in soil. John Wiley and sons Inc., New York, 339, ISSN: 0470215984.

Amadi, A. N., Olasehinde, P. I. \& Nwankwoala, H. O., (2014).Hydrogeochemistry and statistical analysis of Benin Formation in Eastern Niger Delta, Nigeria. International Research Journal of Pure and Applied Chemistry, 4(3), 327-338.

Amadi A. N., Dan-Hassan M. A., Okoye N. O., Ejiofor I. C. \& Aminu Tukur, (2013). Studies on Pollution Hazards of Shallow Hand-Dug Wells in Erena and Environs, North-Central Nigeria. Environment and Natural Resources Research, 3(2), 69 - 77. doi:10.5539/enrr.v3n2p69.

Amadi, A. N. \& Nwankwoala, H. O., (2013).Evaluation of Heavy Metal in Soils from Enyimba Dumpsite in Aba, Southeastern Nigeria Using Contamination Factor and GeoAccumulation Index.Energy and Environment Research, 3(1), 125 - 134. doi:10.5539/eer.v3n1p125.

Amadi, A. N., Olasehinde, P. I., Yisa, J., Okosun, E. A., Nwankwoala, H. O. \& Alkali, Y. B., (2012). Geostatistical assessment of groundwater quality from coastal aquifers of Eastern Niger Delta, Nigeria. Geosciences, 2(3), 51-59, doi: $10.5923 /$ j.geo.20120203.03.

Amadi, A. N., (2011). Quality Assessment of Aba River using Heavy Metal Pollution Index. American Journal of Environmental Eng ine e ring, ( 1 ) 1 - 5 . doi:10.5923/j.ajee.20120201.07.

Amadi, A.N., Olasehinde, P. I., Obaje, N.O., Unuevho, C.I., Yunusa, M.B., Keke, U. and Ameh, I.M., (2017). Investigating the Quality of Groundwater from Hand-dug Wells in Lapai, Niger State, North-central Nigeria using Physico-chemical and Bacteriological Parameters. Minna Journal of Geoscience, 1(1), 77 - 92.

Anglin-Brown, B., Armour A. \& Lalor, G, C., (1995). Heavy metal pollution in Jamaica
1: Survey of cadmium, lead and zinc concentrations in the Kintyre and Hope flat district. Environ. Geochem. Health, 17, 51 -56. doi: 10.1007/BF00146708.

Ankley, G. T.; Lodge, K.; Call, D. J.; Balcer, M. D. \& Smith, B. J. (1992). Heavy metal concentrations in surface sediments in a near shore environment, Jurujba Sound, Southeast Brazil. Environ. Poll. Bull. 48, 405-408.

Caeiro, S., Costa, M. H., Ramos, T. B., Fernandes, F., Silveira, N., Coimbra, A., Medeiros, G. \& Painho, M. (2005). Assessing heavy metal contamination in Sado Estuary sediment: an index analysis approach. Ecol. Indic. 5, 151-169.

Che, Y.G., He, Q. \& Lin, W. Q., (2003).The distributions of particulate heavy metals and its indication to the transfer of sediments in the Changjiang estuary and Hangzhou Bay, China.Mar. Pollut. Bull., 46, 123-131, doi: 10.1016/S0025326X(02)00355-7.

Dineley, D., Hawkes, D., Hancock P. \& Williams, B., (1976). Earth resources - a dictionary of terms and concepts, Arrow Books LTD, London, 205.

Federal Meteorological Agency, Minna, (2011). The meteorological data of Minna, Niger State, Unpublished data.

Gorenc, S., Kostaschuk, R. \& Chen, Z., (2004).Spatial variation in heavy metals on tidal flats in the Yangtze Estuary China.Environ. Geo., 45, 1101 - 1108, doi: 10.1007/s00254-004-0968-5.

Grosheva, E. L.; Voronskaya, G. N. \& Pastukhove, M. V. (2000). Trace element bioavailability in Lake Baikal. Aquat.Ecosys.Health Mange. 3, 229-234.

Kwon, Y. T. \& Lee, C. W. (2001). Sediment metal speciation for the ecological risk assessment.Anal.Sci. 7, 1015-1017.

Lin, C., He, M., Zhou, y., Guo, W. \& Yang, Z. (2002). Distribution and contamination assessment of heavy metals in sediment of the Second Songhua River, China.Soil Sediment Contam. 28, 155-168.

Liu, J., Li, Y., Zhang, B., Cao, J., Cao, Z. \& Domagalski, J. (2009).Ecological risk of heavy metals in sediments of the Luan River source water. Ecotoxicology Journal, 18, 
748-758.

Mielke, H. W., Adams, J. L., Chaney, R. L., Mielke, P. W. Jr., \& Ravikumar, V. C., (1991). The pattern of cadmium in the environment of five Minnesota cities. Environ Geochem. Health, 13, 29-34. doi : 10.1007/BF01783493.

Nachtergaele, F. O. F., Van-Lynden, G. W. J., \& Batjes, N. H., (2002).Soil and terrain databases and their applications with special reference to physical soil degradation and soil Vulnerability to pollution in Central and Eastern Europe. Advanced Geoecology. 35, 45-55.

Nwankwoala, H. O., Angaya, Y. B., Amadi, A. N. and Ameh, I. M., (2017). Contamination Risk Assessment of Physico-chemical and Heavy Metal Distribution in Water and Sediments of the Choba Section of the New Calabar River, Nigeria. Nigeria Journal of Engineering and Applied Sciences, 4(1), $15-24$.

Okunlola, I. A., Amadi, A. N., Olasehinde, P. I., Sani, Sabo \& Okoye, N. O., (2016). Impacts of limestone mining and processing on water quality in Ashaka Area, Northeastern Nigeria.Development Journal of Science and Technology Research, 5(1), $47-62$.

Pascual, B., Gold-Bouchot, G., Ceja-Moreno, V. \& del Ri'o-garci'a, M., (2004).Heavy metal and hydrocarbons in sediments from three lakes from san Miguel,Chiapas, Mexico. Bull. Environ. Contam.Toxicol., 73, 762-769. doi:10.1007/s00128-004-04910.

Prasad, B. \& Kumari, S., (2008). Heavy metal pollution index of ground water of an abandoned open cast mine filled of the water quality of River Adyar, India. Bulletin of Environmental Contamination and Toxicology, 82(2), 211-217.
Preda, M \& Cox, M.E., (2002). Trace metal occurrence and distribution in sediments and mangroves, Pumicestone region, southeast Queenland, Australia. Environment, 28, 433-449.

Russ, W. (1957).The Geology of Part of Niger, Zaria and Sokoto Provinces (with special reference to the occurrence of gold). Geological Survey of Nigeria, (27), 1-42.

Saeed, S. M. \& Shakr, S. F. (2008).Impact of cage fish culture in the River Nileon physicchemical characteristics of water, metals accumulation, histological and some biochemical parameters in fish.Abbassa Int. j. Aqua. (A1),179-202.

Taylor, S.R., \& McLennan, S.M. (1995).The geochemical evolution of continental crust. Rev Geophysics. 33(2), 241-265.

Tijani, M. N., Onodera, S. \& Adeleye, M. A. (2005). Environmental implications of adsorbed and total trace metals concentrations in bottom-sediments of an urban drainage network in a developing country. Mater.Geoenviron. $52(1), 127-130$.

Truswell J.A. \& Cope R.N. (1963). The Geology of Part of Niger and Zaria Provinces, Northern Nigeria, Bull. Geological Survey of Nigeria, 29.

VonGunten, H. R., Sturm, M. \& Moser, R. N. (1997). 200-year recorded of metals in lake sediments and natural background concentrations. Environ. Sci. and Tech. 31(8), 2193- 2197.

Wang, C., Niu, Z., Li, Y., Sun, J. \& Wang, F. (2011). Study on heavy metal concentrations in river sediment through the total amount evaluation method. J. Zhejiang Univ.-Sci. A (Appl. Phys. and Eng.), 12(5), 399-404.

Wedepohl, K. H. (1995). The composition of the continental crust.Geochim Cosmochim Acta.59 (7), 1217-1232. 